\title{
Does monosodium glutamate really cause headache? : a systematic review of human studies
}

\author{
Yoko Obayashi $^{1 *}$ and Yoichi Nagamura ${ }^{2}$
}

\begin{abstract}
Although monosodium glutamate (MSG) is classified as a causative substance of headache in the International Classification of Headache Disorders 3rd edition (ICHD-III beta), there is no literature in which causal relationship between MSG and headache was comprehensively reviewed. We performed systematic review of human studies which include the incidence of headache after an oral administration of MSG. An analysis was made by separating the human studies with MSG administration with or without food, because of the significant difference of kinetics of glutamate between those conditions (Am J Clin Nutr 37:194-200, 1983; J Nutr 130:1002S-1004S, 2000) and there are some papers which report the difference of the manifestation of symptoms after MSG ingestion with or without food (Food Chem Toxicol 31:1019-1035, 1993; J Nutr 125:2891S-2906S, 1995). Of five papers including six studies with food, none showed a significant difference in the incidence of headache except for the female group in one study. Of five papers including seven studies without food, four studies showed a significant difference. Many of the studies involved administration of MSG in solution at high concentrations (>2\%). Since the distinctive MSG is readily identified at such concentrations, these studies were thought not to be properly blinded. Because of the absence of proper blinding, and the inconsistency of the findings, we conclude that further studies are required to evaluate whether or not a causal relationship exists between MSG ingestion and headache.
\end{abstract}

Keywords: Monosodium glutamate (MSG), Headache, International classification of headache disorders (ICHD), Systematic review, Human study, Chinese restaurant syndrome (CRS)

\section{Background}

Monosodium glutamate is used worldwide as a flavor enhancer. So called Chinese restaurant Syndrome (CRS) was first reported by Kwok in 1968 [1]. He reported that after consumption of Chinese dishes, some transient subjective symptoms occurred such as numbness, general weakness, palpitation, etc. Although many human studies were conducted afterwards to determine if a causal relationship occurs between MSG and this symptom complex, the results were inconsistent. Headache was reported to be one of this symptom complex.

The safety of glutamic acid and its salts as flavor enhancers was evaluated by the Joint FAO/WHO Expert Committee on Food Additives in 1971 [2], 1974 [3], and

\footnotetext{
* Correspondence: obayashiy@ajiusa.com

${ }^{1}$ International Glutamate Technical Committee (IGTC), Avenue Jules Bordet

142, B-1140 Brussels, Belgium

Full list of author information is available at the end of the article
}

1987 [4] and it allocated an "acceptable daily intake (ADI) not specified" based on the conclusion that the total intake of glutamate arising from their use at levels necessary to achieve the desired technological effect and from their acceptable background in food do not represent a hazard to health.

In this review, we report the results of a systematic review of available human studies of MSG, focusing on the causal relationship between MSG intake and headache by separate analysis of the studies with MSG administration with or without food. We also discuss the scientific validation of ICHD-III beta on MSG [5], based on our review of the studies cited.

\section{Review \\ Methods}

Since most of the human studies that include data on the headache incidence focus on symptom complex and 
do not specifically focus on headache, search condition was optimized to obtain as many human study data with MSG administration as possible.

The literature search was conducted on Medline and FSTA. Initially, we searched for titles that includes any of the following terms: "monosodium glutamate", "MSG", "monosodium L-glutamate", "sodium glutamate", and "sodium L-glutamate". In case of Medline, the search was narrowed down by specifying article type as "clinical trial". The above search result was further narrowed down by the following conditions; (1) the paper is written in English, (2) the paper is a human study with the administration of MSG using healthy adults, (3) the incidence of headache is shown, and (4) a statistical analysis was performed on the incidence of headache, or the paper includes sufficient data with which to perform statistical analysis.

\section{Results and discussion}

\section{Result of the literature search}

The literature search identified eight human studies using Medline and two human studies using FSTA that met our inclusion criteria. Of these ten papers, five papers were the human studies with the MSG administration with food and the dose of MSG was 1.5 $3.15 \mathrm{~g}$ [6-10]. The other five papers were the studies with the MSG administration without food and the dose of MSG was 1.25 - $12 \mathrm{~g}$ [11-15]. The outline of these studies is shown in Tables 1 and 2. ICHDIII beta referenced five papers concerning MSG in section $8.1[6,12,16-18]$. The outline of these papers is shown in Tables 3 and 4 .

\section{Blind integrity}

The normal content of added MSG in food is $0.2-0.8 \%$ for appropriate taste. Kenny reported that the subjects responded favorably in terms of taste and palatability of tomato juice containing $1 \mathrm{~g}$ MSG in $150 \mathrm{ml}$ and less favorably when larger quantities $(>2 \mathrm{~g})$ were given [17]. In addition, Gore reported that there were statistically significant difference between the taste and after taste of 1-4\% MSG dissolved in water compared with placebo solution [16]. It is also reported that high dose of MSG causes various adverse gastrointestinal reactions, leading to vomiting at very high dose [19]. Taken together, it can be assumed that the beverage containing $1.3 \%$ MSG ( $2 \mathrm{~g} / 150 \mathrm{ml}-)$ or more should be distinguishable from placebo beverage and have an unfavorable taste.

Therefore, we analyzed the human studies, especially paying attention to the blind integrity and validity of the data.

\section{Human studies with MSG administration with food}

Regarding the studies with the MSG administration with food, five papers which include six studies were found (Table 1).
On the study reported by Praworphardjono [7] and at the first stage of Tarasoff's study [6], 1.5, 3.0 g MSG or placebo in capsules was administered in fasted conditions, followed by the ingestion of a standardized breakfast. At the second stage of Tafasoff"s study, the subjects ingested a specially formulated soft drink which included 3.15 g MSG or placebo, and then consumed the standardized breakfast. Although at this second stage, some subjects might be able to distinguish placebo and MSG beverage, they analyzed only the data from 61 subjects, who reported no after-taste, out of 71 subjects. In all studies by Praworphardjono and Tarasoff, no difference of incidence of headache between placebo and MSG administration was found and the authors concluded that rigorous and realistic scientific evidence linking CRS to MSG could not be found.

Tanphaichitr investigated the incidence of unpleasant symptoms after ingestion of a breakfast containing added MSG or no added MSG [8]. In the first experiment, using ten subjects, a menu that masked the taste of MSG was identified. Four menus without MSG and one menu with $3 \mathrm{~g}$ MSG were served to 50 subjects as a breakfast on day 1-5 one-by-one. No one served with the menu containing MSG had a headache and the author concluded that the addition of MSG did not cause significant difference in unpleasant symptoms of CRS from those on menu without MSG.

Thus, those three studies above can be thought properly blinded, but the following two studies reported by Zanda [9] and Morselli [10] might not ensure the sufficient blind integrity. In both studies, $3 \mathrm{~g}$ MSG in $150 \mathrm{ml}$ beef broth (2\%) was administered followed by other dishes. No significant difference in the incidence of CRS symptoms was found in both studies, with the exception of headache occurrence among females in Zanda's study: an incidence in 6 subjects was observed on the MSG day, but only 1 on the placebo day $(P<0.05)$. Clinically meaningful differences in objective indices, such as arterial blood pressure and pulse rate, were not observed. In total 73 subjects (38 males, 35 females) joined this study. We note that the number of migrainers is higher in females than in males (France; male $6.35 \%$, female $15.7 \%$, USA; male $6.6 \%$, female $19.2 \%$ ) [20], and unpleasant taste and unfavorable sensation caused by high dose of MSG may become a stimulant to trigger headache on migrainers especially when they are fasted. Placebo effect by distinguishable taste also should not be ignored.

In the study by Morselli, they concluded that no difference in all CRS symptoms including headache between the subjects given MSG and control broth.

\section{Human studies with MSG administration without food}

Regarding the studies of MSG administration without food, we found five papers containing seven studies 
Table 1 Human studies of MSG with food

\begin{tabular}{|c|c|c|c|c|c|}
\hline First author & $\begin{array}{l}\text { Vehicle for MSG } \\
\text { administration }\end{array}$ & Protocol & Number of subjects & Incidence of headache & $\overline{\text { Statistical difference }}$ \\
\hline $\begin{array}{l}\text { Prawirohardjono } \\
\text { W (2000) [7] }\end{array}$ & Opaque capsule & $\begin{array}{l}\text { (1)In the morning, after fasting } \\
\text { for } 10 \text { h, subjects ingested three } \\
\text { capsules containing MSG }(0.5 \mathrm{~g} \\
\text { MSG \& } 0.5 \mathrm{~g} \text { lactose or } 1.0 \mathrm{~g} \\
\text { MSG) or placebo( } 1.0 \mathrm{~g} \text { lactose). } \\
\text { (2)A standardized breakfast was } \\
\text { provided and consumed } \\
\text { immediately after capsule } \\
\text { ingestion. }\end{array}$ & $\begin{array}{l}52 \text { healthy volunteers (Indonesians) } \\
\text { (Mean age } 29.6 \pm 6.5 \mathrm{y} \text {, mean mass } \\
53.4 \pm 7.4 \mathrm{~kg} \text {, mean height } 159.9 \pm \\
7.7 \mathrm{~cm} \text { ) }{ }^{*} \text { No indication about gender. }\end{array}$ & $\begin{array}{l}\text { Placebo : } 3 \\
1.5 \mathrm{~g} \mathrm{MSG}: 4 \\
3.0 \mathrm{~g} \mathrm{MSG}: 2\end{array}$ & No difference \\
\hline \multirow[t]{2}{*}{ Tarasoff L (1993) [6] } & Capsule & $\begin{array}{l}\text { Fasting condition } \\
\text { On first } 3 \text { days, } 6 \text { capsules } \\
\text { immediately followed by } \\
\text { breakfast. }\end{array}$ & $\begin{array}{l}71 \text { healthy volunteers (female: } 41 \text {, } \\
\text { mean age:30.7) }\end{array}$ & $\begin{array}{l}\text { Placebo (gelatin powder): } 1 \\
1.5 \text { g MSG: } 0 \\
3.0 \text { g MSG: } 0\end{array}$ & No difference \\
\hline & $\begin{array}{l}\text { Specially formulated } \\
\text { drinks }\end{array}$ & $\begin{array}{l}\text { On remaining } 2 \text { days, } 300 \mathrm{ml} \text { soft } \\
\text { drink immediately followed by } \\
\text { breakfast. }\end{array}$ & *Mainly Caucasians & $\begin{array}{l}\text { Placebo (drink): } 0 \\
3.15 \text { g MSG (drink): } 0\end{array}$ & No difference \\
\hline $\begin{array}{l}\text { Tanphaichitr V } \\
\text { (1983) [8] }\end{array}$ & Boiled rice with pork & $\begin{array}{l}\text { Menu A-D(w/o MSG), E(added } \\
3 \mathrm{~g} \text { MSG) were serve as breakfast } \\
\text { on Day } 1-5 \text { by this order. }\end{array}$ & 50 adults (male:25, female:25) & $\begin{array}{l}\text { Menu A(w/o MSG):4 } \\
\text { Menu B(w/o MSG):0 } \\
\text { Menu C(w/o MSG):2 } \\
\text { Menu D(w/o MSG):2 } \\
\text { Menu E(3 g MSG):0 }\end{array}$ & No difference \\
\hline \multirow[t]{2}{*}{ Zanda G (1973) [9] } & Beef bouillon & $\begin{array}{l}3 \text { g MSG(placebo: no MSG, no } \\
\text { substitute) in } 150 \text { ml beef } \\
\text { bouillon followed by other } \\
\text { dishes. } \\
\text { [First session] Some subjects at } \\
\text { random received MSG. } \\
\text { [Second session( } 2 \text { days later)] } \\
\text { Opposite to the first session }\end{array}$ & $\begin{array}{l}73 \text { healthy volunteers (male:38, } \\
\text { female:35, mean age: } 25,17-76 y \text { ) }\end{array}$ & $\begin{array}{l}\text { Control(male): } 1 \\
\text { Control(female):1 } \\
3 \text { g MSG (male):1 } \\
3 \text { g MSG (female): } 6^{*}(P<0.05) \\
\text { Responded to both (male):2 } \\
\text { Responded to both (female):2 }\end{array}$ & $\begin{array}{l}\text { Only MSG-treated } \\
\text { women had a } \\
\text { significantly higher } \\
\text { incidence of } \\
\text { headache than } \\
\text { control. }\end{array}$ \\
\hline & & $\begin{array}{l}\text { Blood pressure and pulse rate } \\
\text { were also recorded. }\end{array}$ & & & \\
\hline Morselli PL (1970) [10] & Beef broth & $\begin{array}{l}3 \mathrm{~g} \text { MSG in } 150 \mathrm{ml} \text { beef broth } \\
\text { followed by other dishes(meat, } \\
\text { vegetables, fruit). } \\
\text { [First session] MSG:8 sub., } \\
\text { control: } 16 \text { sub. } \\
\text { [Second session( } 2 \text { days later)] } \\
\text { Opposite to the first session }\end{array}$ & $\begin{array}{l}24 \text { healthy volunteers (male:17, } \\
\text { female:7) }\end{array}$ & $\begin{array}{l}\text { Control: } 1 \\
3 \text { g MSG: } 2\end{array}$ & No difference \\
\hline
\end{tabular}


Table 2 Human studies of MSG without food

\begin{tabular}{|c|c|c|c|c|c|}
\hline Researcher & $\begin{array}{l}\text { Vehicle for MSG } \\
\text { administration }\end{array}$ & Protocol & Number of subjects & Incidence of headache & Statistical difference \\
\hline Geha RS (2000) [11] & $\begin{array}{l}200 \mathrm{ml} \text { of citrus- } \\
\text { flavored beverage }\end{array}$ & $\begin{array}{l}\text { [Protocol A] } \\
5 \mathrm{~g} \text { MSG and placebo (0 g MSG) } \\
\text { on separate day (day } 1 \& 2 \text { ) }\end{array}$ & $\begin{array}{l}130 \text { self-reported MSG-reactive } \\
\text { volunteers (female:84, male:46) }\end{array}$ & $\begin{array}{l}\text { [Frequency] } \\
\text { Placebo: } 0.28 \\
5 \text { g MSG: } 0.54(P<0.005)^{* *}\end{array}$ & Significant difference \\
\hline \multirow[t]{2}{*}{ Yang WH (1997) [12] } & \multirow{2}{*}{$\begin{array}{l}200 \mathrm{ml} \text { of a strongly } \\
\text { citrus-tasting } \\
\text { beverage sweetened } \\
\text { by sucrose. }\end{array}$} & $\begin{array}{l}\text { (1) } 5 \text { g MSG or placebo(0 g MSG) } \\
\text { (empty stomach) }\end{array}$ & $\begin{array}{l}61 \text { subjects self-identified MSG- } \\
\text { sensitive people (male:15, white:59, } \\
\text { black:1, oriental:1) }\end{array}$ & $\begin{array}{l}\text { Placebo: } 24 \\
5 \text { g MSG: } 23\end{array}$ & No difference \\
\hline & & $\begin{array}{l}\text { (2) placebo( } 0 \mathrm{~g} \text { MSG, no } \\
\text { substitute), } 1.25,2.5,5 \mathrm{~g} \text { MSG in } \\
\text { random sequence. }\end{array}$ & $\begin{array}{l}36 \text { subjects Subjects who responded } \\
\text { to either of MSG or placebo in } \\
\text { study(1) (not both or not neither). } \\
\text { No indication about gender. }\end{array}$ & $\begin{array}{l}\text { Placebo: } 9 \\
1.25 \text { g MSG: } 11 \\
2.5 \text { g MSG: } 16(P<0.04)^{*} \\
5 \text { g MSG: } 18(P<0.023)^{*}\end{array}$ & $\begin{array}{l}1.25 \mathrm{~g} \text { : no difference } \\
2.5,5 \mathrm{~g}: \text { significant } \\
\text { difference }\end{array}$ \\
\hline Shimada A (2013) [13] & $\begin{array}{l}400 \mathrm{ml} \text { Sugar-free } \\
\text { lemon soda }\end{array}$ & $\begin{array}{l}\text { MSG }(150 \mathrm{mg} / \mathrm{kg}=9 \mathrm{~g} / 60 \mathrm{~kg}) \text { for } \\
5 \text { consecutive days (in the week) } \\
\text { and } \mathrm{NaCl}(24 \mathrm{mg} / \mathrm{kg}) \text { in the other } \\
\text { week in randomized sequence. }\end{array}$ & 14 healthy adults (female:9, male:5) & $\begin{array}{l}\text { Placebo: } 2 \\
150 \mathrm{mg} / \mathrm{kg} \text { MSG }(=9 \mathrm{~g} / 60 \mathrm{~kg}): 8^{*} \\
(P=0.041)\end{array}$ & Significant difference \\
\hline Baad-Hansen L (2010) [14] & $\begin{array}{l}400 \mathrm{ml} \text { Sugar-free } \\
\text { soda }\end{array}$ & $\begin{array}{l}\mathrm{NaCl}(24 \mathrm{mg} / \mathrm{kg}), \mathrm{MSG}(75 \mathrm{or} \\
150 \mathrm{mg} / \mathrm{kg}=6 \text { or } 9 \mathrm{~g} / 60 \mathrm{~kg}) \text { in } \\
\text { random sequence. }\end{array}$ & 14 healthy men & $\begin{array}{l}\text { Placebo: } 0 \\
75 \mathrm{mg} / \mathrm{kg} \text { MSG }(=4.5 \mathrm{~g} / 60 \mathrm{~kg}): 27^{*} \\
(\mathrm{P}=0.045 \text {, vs placebo and } \\
150 \mathrm{mg} / \mathrm{kg} \text { MSG) } \\
150 \mathrm{mg} / \mathrm{kg} \text { MSG (=9 g/60 kg): } 7\end{array}$ & $\begin{array}{l}75 \mathrm{mg} / \mathrm{kg}: \text { significant } \\
\text { difference } 150 \mathrm{mg} / \mathrm{kg} \text { : no } \\
\text { difference }\end{array}$ \\
\hline \multirow[t]{2}{*}{ Rosenblum I (1971) [15] } & $\begin{array}{l}100 \mathrm{ml} \text { tap water or } \\
\text { chicken stock }\end{array}$ & $\begin{array}{l}15 \mathrm{~h} \text { after the last meal. } \\
\text { (Group I-IV) } 5 \mathrm{~g} \mathrm{MSG} \text { in tap } \\
\text { water(49 subjects) or chicken } \\
\text { stock(49 sub.). } \\
\text { (Group V) } 1.7 \mathrm{~g} \mathrm{NaCl} \text { in chicken } \\
\text { stock( } 24 \text { sub.) } \\
\text { (Group VI) chicken stock(25 sub.). }\end{array}$ & 99 male volunteers, 21-59 years old. & $\begin{array}{l}\text { [Frequency] } \\
\text { Placebo(Group V, VI):8 \% } \\
5 \text { g MSG(Group I-IV):17 \% }\end{array}$ & No difference \\
\hline & $100 \mathrm{ml}$ chicken stock & $\begin{array}{l}\text { (Group VII) } 8 \mathrm{~g}(6 \text { sub.) MSG in } \\
\text { chicken stock, } 2.8 \mathrm{~g} \mathrm{NaCl} \text { in } \\
\text { chicken stock(5 sub.). } \\
\text { (Group VIII) } 12 \mathrm{~g} \mathrm{MSG} \text { in chicken } \\
\text { stock(5 sub.), } 4.2 \mathrm{~g} \mathrm{NaCl} \text { in } \\
\text { chicken stock (5 sub). }\end{array}$ & $\begin{array}{l}11 \text { people Chosen from the original } \\
99 \text { subjects, based on the results of } \\
\text { the test above. One-half reported } \\
\text { multiple complaints on the } \\
\text { questionnaire while the other } \\
\text { reported no complaints. }\end{array}$ & $\begin{array}{l}\text { Placebo(NaCl2.8 g):2 } \\
8 \text { g MSG(VII):3 } \\
\text { Placebo(NaCl4.2 g):0 } \\
12 \text { g MSG(VIII):2 }\end{array}$ & No difference \\
\hline
\end{tabular}

*; Statistically significant difference was found between placebo and MSG group $(P<0.05)$

**; Statistically significant difference was found between placebo and MSG group $(P<0.01)$ 
Table 3 Human studies of MSG which were referenced by ICHD-III beta

\begin{tabular}{|c|c|c|c|c|c|c|}
\hline First author & study type & $\begin{array}{l}\text { Number of } \\
\text { subjects }\end{array}$ & MSG administration & $\begin{array}{l}\text { with }(w) \text { or } \\
\text { without(w/o) food }\end{array}$ & $\begin{array}{l}\text { Statistical analysis } \\
\text { in the paper }\end{array}$ & $\begin{array}{l}\text { statistical } \\
\text { difference }\end{array}$ \\
\hline \multirow{2}{*}{$\begin{array}{l}\text { Tarasoff L } \\
\text { (1993) [6] }\end{array}$} & \multirow[t]{2}{*}{ human study } & \multirow[t]{2}{*}{71} & capsule & w & performed & No difference \\
\hline & & & $3.15 \mathrm{~g} \mathrm{MSG} / 300 \mathrm{ml}$ soft drink & w & performed & No difference \\
\hline \multirow[t]{2}{*}{$\begin{array}{l}\text { Yang WH } \\
(1997)[12]\end{array}$} & \multirow[t]{2}{*}{ human study } & $\begin{array}{l}61 \text { (self-identified } \\
\text { MSG sensitive) }\end{array}$ & $\begin{array}{l}5 \mathrm{~g} \mathrm{MSG} / 200 \mathrm{ml} \text { strongly } \\
\text { citrus-tasting beverage }\end{array}$ & w/o & performed & No difference \\
\hline & & $\begin{array}{l}\text { 36(self-identified } \\
\text { MSG sensitive) }\end{array}$ & $\begin{array}{l}1.25-5 \mathrm{~g} \mathrm{MSG} / 200 \mathrm{ml} \text { strongly } \\
\text { citrus-tasting beverage }\end{array}$ & w/o & performed & $\begin{array}{l}2.5,5 \mathrm{~g} \text { : Significant } \\
\text { difference }\end{array}$ \\
\hline $\begin{array}{l}\text { Gore M } \\
\text { (1980) [16] }\end{array}$ & human study & 55 & 1.5-6 g MSG/150 ml tap water & w/o & not performed & $\begin{array}{l}\text { No difference } \\
\text { (Fisher test) }\end{array}$ \\
\hline \multirow[t]{2}{*}{$\begin{array}{l}\text { Kenny RA } \\
(1972)[17]\end{array}$} & \multirow[t]{2}{*}{ human study } & 77 & $5 \mathrm{~g} \mathrm{MSG} / 150 \mathrm{ml}$ tomato juice & w/o & not performed & $\begin{array}{l}\text { No difference } \\
\text { (Fisher test) }\end{array}$ \\
\hline & & 22 & $\begin{array}{l}1-5 \mathrm{~g} \mathrm{MSG} / 150 \mathrm{ml} \text { tomato } \\
\text { juice or water }\end{array}$ & w/o & not performed & cannot analyze \\
\hline $\begin{array}{l}\text { Merrit JE } \\
\text { (1990) [18] }\end{array}$ & in vitro & & & & & \\
\hline
\end{tabular}

(Table 2). In all of those studies, MSG dissolved in beverage or soup at relatively high concentrations (1.125 $12 \%)$ was administered to the subjects.

A statistical difference of incidence of headache was reported in four out of seven studies. In two of those four studies reported by Geha [11] and Yang [12], self-identified MSG sensitive subjects were recruited and $200 \mathrm{ml}$ of a citrus-flavored beverage with or without MSG was administered to 130 and 36 subjects, respectively. In Geha's study, the dose of MSG was $5 \mathrm{~g}(2.5 \%)$ and the significant difference of incidence of headache in MSG group was found. Yang's study was composed of two studies and the first study did not show statistical difference, despite of a large amount of MSG, i.e. $5 \mathrm{~g}$ (2.5 \%), ingested. However, at the second stage, in which the subjects reacted to either of MSG or placebo at the first stage joined, a significant difference in the incidence of

Table 4 Human studies of MSG which were referenced by ICHD-III beta but were not complied with the criteria for the systematic review

\begin{tabular}{|c|c|c|c|c|c|}
\hline First author & $\begin{array}{l}\text { Vehicle for } \\
\text { MSG administration }\end{array}$ & Protocol & Number of subjects & Incidence of headache & Statistical difference \\
\hline $\begin{array}{l}\text { Gore M } \\
(1980)[16]\end{array}$ & $\begin{array}{l}150 \mathrm{ml} \text { cold } \\
\text { tap water }\end{array}$ & $\begin{array}{l}\text { After an overnight fast, } \\
\text { subjects ingested, on different } \\
\text { days, } 1.5,3,6 \mathrm{~g} \mathrm{MSG} \text { and three } \\
\text { paired placebo materials, the } \\
\text { order of each pair being } \\
\text { randomized. (There was no } \\
\text { indication about the content } \\
\text { "three paired placebo } \\
\text { materials") }\end{array}$ & 30 men, 25 women & $\begin{array}{l}\text { [Total number of positive } \\
\text { responses by } 3 \text { doses] } \\
\text { MSG: } 8 \text { episodes ( } 7 \text { subjects), } \\
\text { Placebo: } 2 \text { episodes } \\
\text { ( } 2 \text { subjects) }\end{array}$ & $\begin{array}{l}\text { No difference } \\
\text { (Fisher test) } \\
\text { Statistical analysis in each } \\
\text { symptom was not } \\
\text { performed in the paper. }\end{array}$ \\
\hline \multirow[t]{2}{*}{$\begin{array}{l}\text { Kenny RA } \\
\text { (1972) [17] }\end{array}$} & $\begin{array}{l}150 \mathrm{ml} \text { tomato } \\
\text { juice }\end{array}$ & $\begin{array}{l}\text { (Phase 1) } \\
2 \text { h after breakfast, } 5 \mathrm{~g} \mathrm{MSG} \\
\text { on1 day and } 0.8 \mathrm{~g} \mathrm{NaCl} \text { on the } \\
\text { other } 2 \text { days. } \\
\text { Breakfast type: } \\
\text { (1)no breakfast } \\
\text { (2)liquids (milk, coffee, juice) or } \\
\text { instant breakfast } \\
\text { (3)largely of } \\
\text { carbohydrate(cereal, toast, etc.) } \\
\text { (4)containing protein (eggs, } \\
\text { ham, etc.) }\end{array}$ & $\begin{array}{l}\text { (Phase 1) } 77 \\
\text { subjects }\end{array}$ & $\begin{array}{l}\text { [Number of positive } \\
\text { responses] } \\
\text { MSG : } 4 \text {, Placebo : } 2\end{array}$ & $\begin{array}{l}\text { No difference } \\
\text { (Fisher test) } \\
\text { Statistical analysis was not } \\
\text { performed in the paper. }\end{array}$ \\
\hline & $\begin{array}{l}150 \mathrm{ml} \text { tomato } \\
\text { juice }(\mathrm{J}) \text { or } \\
\text { water }(\mathrm{W})\end{array}$ & $\begin{array}{l}\text { (Phase 2) } \\
\text { JP1 : } 0.8 \mathrm{~g} \mathrm{NaCl}, \text { WP: } 0.7 \mathrm{~g} \\
\mathrm{NaCl} \\
\text { WM5 : } 5 \mathrm{~g} \mathrm{MSG}+0.2 \mathrm{~g} \mathrm{NaCl} \\
\mathrm{JM} 1: 1 \mathrm{~g} \mathrm{MSG}, \mathrm{JM} 2: 2 \mathrm{~g} \mathrm{MSG}, \\
\mathrm{JM} 3: 3 \mathrm{~g} \mathrm{MSG}, \mathrm{JM} 4: 4 \mathrm{~g} \mathrm{MSG} \\
\mathrm{JP} 2: 0.8 \mathrm{~g} \mathrm{NaCl}\end{array}$ & $\begin{array}{l}\text { (Phase 2) } \\
22 \text { out of } 25 \text { subjects, } \\
\text { Who reacted only to } \\
\text { MSG on phase } 1 \text { study }\end{array}$ & $\begin{array}{l}\text { [Number of positive } \\
\text { responses / subjects] } \\
\text { JM1 : } 1 / 15, \text { JM2 }: 2 / 13 \\
\text { JM3 }: 4 / 13, \text { JM4 }: 5 / 14 \\
\text { WM5 : 8/17 }\end{array}$ & $\begin{array}{l}\text { Since the incidence of } \\
\text { placebo group (JP1, WP, } \\
\text { JP2) is not shown, } \\
\text { statistical analysis cannot } \\
\text { be done. }\end{array}$ \\
\hline
\end{tabular}


headache at the dose of 2.5 and 5.0 g MSG (1.25 and $2.5 \%)$ and the dose dependency was reported.

Among three other studies using subjects who were not restricted to self-identified MSG sensitive subjects, a significant difference in the incidence of headache was found in two studies, both of which originated in the same laboratory in Denmark [13, 14]. In the first study reported by Baad-Hansen, $400 \mathrm{ml}$ sugar-free soda containing MSG (75 or $150 \mathrm{mg} / \mathrm{kg}$ ) or $\mathrm{NaCl}(24 \mathrm{mg} / \mathrm{kg}$ ) was administered to 14 healthy men [14]. These doses correspond to $4.5 \mathrm{~g}(1.125 \%)$ and $9.0 \mathrm{~g}(2.25 \%) / 400 \mathrm{ml}$ $60 \mathrm{~kg}$ b.w., respectively. A significant difference in the incidence of headache was observed at the $75 \mathrm{mg} / \mathrm{kg}$ dose of MSG, but not at the $150 \mathrm{mg} / \mathrm{kg}$ dose compared to the $\mathrm{NaCl}$ placebo. In the second study reported by Shimada, the protocol and the number of subjects were the same as in the first study, except that the number of days in one session was increased from 1 to 5 days to amplify the incidence and the MSG dose was $150 \mathrm{mg} / \mathrm{kg}$, along with the placebo $24 \mathrm{mg} / \mathrm{kg} \mathrm{NaCl}$ [13]. During one session, either of MSG or $\mathrm{NaCl}$ was administered. The $400 \mathrm{ml}$ volume and the high dose of MSG, especially $150 \mathrm{mg} / \mathrm{kg}$, are thought to be sufficient to cause gastrointestinal unpleasant sensation attributable to unfavorable taste and high osmotic pressure. The other issue of these studies are that the content of sodium in placebo $(24 \mathrm{mg} / \mathrm{kg})$ corresponds to $75 \mathrm{mg} / \mathrm{kg}$ MSG and half of $150 \mathrm{mg} / \mathrm{kg}$ MSG. It means that the saltiness and osmotic pressure caused by placebo solution was much less than MSG solution of $150 \mathrm{mg} / \mathrm{kg}$ dose. In addition, the number of $14 \mathrm{sub}$ jects is too small to permit any conclusion regarding large population.

On the other hand, in Rosenblum's study using 99 male subjects, 5, 8, 12 g MSG (5, 8, $12 \%)$ and osmotically equivalent dose of $\mathrm{NaCl}$ dissolved in $100 \mathrm{ml}$ tap water or chicken stock was administered [15]. A significant difference in the incidence of headache was not observed at any dose.

Thus, the results of those studies are inconsistent and it is difficult to conclude whether MSG ingestion without food causes headache. The effect of blind integrity seems to be more influential to self-identified MSGsensitive subjects.

\section{Human studies which were cited by ICHD-III beta}

Among the five papers cited (Table 3), two complied with our search criteria, and are discussed above $[2,11]$. The other two human study papers which did not comply with our search criteria were authored by Gore and Kenny, respectively (Table 4) [16, 17]. Gore's paper does not contain the term meaning "monosodium-L-glutamate" in the title, and in Kenny's paper, the statistical analysis could not be performed due to a lack of placebo data. Statistical analysis was not performed in either papers.
The remaining one paper by Meritt was an in vitro study [18].

Gore et al. reported the study using 55 subjects. They ingested 1.5, 3, 6 g MSG and three paired placebo materials dissolved in $150 \mathrm{ml}$ cold tap water on different days [16]. The incidence of headache was shown as a total number of incidences by three doses, which did not show statistical difference according to our analysis.

In the study reported by Kenny et al., MSG-reactors were screened from 77 subjects at the first study by the administration of $150 \mathrm{ml}$ tomato juice with $5 \mathrm{~g}$ MSG or $0.8 \mathrm{~g} \mathrm{NaCl}$ [17]. According to our analysis, a statistical difference in the incidence of headache was not observed in the first study. Twenty-two MSG-reactors, who suffered from any symptoms in the first study, formed test groups in the second study and were administered 1-5 g MSG dissolved in $150 \mathrm{ml}$ tomato juice or water. We could not perform a statistical analysis on the results, due to a lack of placebo data.

Among above-mentioned four papers on human studies, consisting of six studies, a statistical difference was found only in one study reported at the second stage of Yang's study, which is aforementioned.

The in vitro study authored by Merrit focused on a direct effect of MSG on contraction and relaxation of rabbit aorta. However, we should pay attention to the little impact of MSG ingestion on plasma glutamate level, especially when MSG is ingested with food as a flavor enhancer [21]. Tsai et al. reported the circadian variation of plasma glutamate level when the meals added $100 \mathrm{mg} / \mathrm{kg}$ MSG $(15,40,45 \mathrm{mg} / \mathrm{kg}$ to breakfast, lunch and dinner) were given to healthy adult men. It ranged between 33 and $48 \mu \mathrm{mol} / \mathrm{l}$ on days without added MSG, and 32 and $53 \mu \mathrm{mol} / \mathrm{l}$ on days with added MSG [22]. Although $100 \mathrm{mg} / \mathrm{kg}$ MSG (6 g MSG/60 kg bw) is much larger dose than the average MSG intake from food (estimated intake of added glutamate is c.a. $0.4 \mathrm{~g}$ in Europe and 1.2-1.7 $\mathrm{g}$ in Asian countries [23]), about $10 \%$ change of circadian variation can be regarded as being within the rage of daily variation.

Taken together, it is difficult to argue from this group of studies that MSG causes headache.

\section{Conclusion}

Among human studies with the MSG administration with food, significant difference of headache incidence was not found at the dose of 1.5 and $3.0 \mathrm{~g}$ in capsule, $3.15 \mathrm{~g} / 300 \mathrm{ml}$ beverage, $3.0 \mathrm{~g}$ in boiled rice with pork, and $3.0 \mathrm{~g} / 150 \mathrm{ml}$ beef broth. The significant difference was found only in female administered $3.0 \mathrm{~g}$ MSG/ $150 \mathrm{ml}(2.0 \%)$ beef bouillon but not in male.

In all the studies with MSG administration without food, MSG was administered, being dissolved in beverages 
or soup at relatively high concentrations (1.125-12 \%). In those studies, significant difference of headache incidence was found at the dose of $2.5 \mathrm{~g} / 200 \mathrm{ml}, 5.0 \mathrm{~g} / 200 \mathrm{ml}, 6 \mathrm{~g} /$ $400 \mathrm{ml} \cdot 60 \mathrm{~kg} \mathrm{bw}, 9 \mathrm{~g} / 400 \mathrm{ml} \cdot 60 \mathrm{~kg} \mathrm{bw}$, but not found at $1.25 \mathrm{~g} / 200 \mathrm{ml}, 5.0 \mathrm{~g} / 200 \mathrm{ml}, 9 \mathrm{~g} / 400 \mathrm{ml} \cdot 60 \mathrm{~kg}$ bw, $5.0 \mathrm{~g} / 100 \mathrm{ml}, 8.0 \mathrm{~g} / 100 \mathrm{ml}, 12.0 \mathrm{~g} / 100 \mathrm{ml}$.

We should pay attention to the blind integrity of the human studies where high dose of MSG was administered in solution, especially focusing on the distinguishable and unpleasant taste of MSG solutions at $1.3 \%$ $(2 \mathrm{~g} / 150 \mathrm{ml})$ or more and the gastrointestinal discomfort caused by high dose of MSG. These events may influence the occurrence of headache quite strongly especially in case of migrainers and the subjects who believe they are MSG-sensitive.

From the fact that the results of the human studies are not consistent and it is assumed that most studies using beverages as a vehicle are not properly blinded, we suggest that a causal relationship between MSG and headache has not been proven. In addition, statistically significant differences in the incidence of headache were not observed when MSG was administered with food, except in one case of the female group where the blind integrity was questionable. It would seem premature to conclude that the MSG present in food causes headache.

\section{Abbreviations}

MSG: monosodium glutamate; ICHD: international classification of headache disorders; CRS: Chinese restaurant syndrome; FSTA: food science technology abstracts; ADI: acceptable daily intake.

\section{Competing interests}

$\mathrm{YO}$ is an employee of MSG manufacturer which joins International Glutamate Technical Committee (IGTC). IGTC is an international scientific non-profit organization, dedicated to the support of targeted scientific research on the biochemistry/metabolism, physiology, pharmacology and toxicology of glutamic acid. IGTC finances the publication fee of this manuscript. YN has no competing interests.

\section{Authors' contributions}

YO performed systematic review by collecting and analyzing articles, and drafted the manuscript. YN has given final approval for publication of the manuscript, ensuring accuracy and integrity of the manuscript. Both authors have read and approved the final manuscript.

\section{Authors' information}

YO was the scientific adviser of IGTC. YN has no official relationship with IGTC.

\section{Author details}

${ }^{1}$ International Glutamate Technical Committee (IGTC), Avenue Jules Bordet 142, B-1140 Brussels, Belgium. ²Faculty of Health Science, Department of Clinical Nurition, Suzuka University of Medical Science, 1001-1 Kishioka-cho, Suzuka-city, Mie 510-0293, Japan.

Received: 19 November 2015 Accepted: 14 January 2016 Published online: 17 May 2016

\section{References}

1. Kwok RH (1968) Chinese-restaurant syndrome. N Engl J Med 278(14):796

2. FAO/WHO (1971) Evaluation of food additives: specifications for the identity and purity of food additives and their toxicological evaluation; some extraction solvents and certain other substances; and a review of the technological efficiency of some antimicrobial agents. 14th Report of the
Joint FAO/WHO Expert Committee on Food Additives. FAO Nutrition Meetings Report Series no. 48, WHO Technical Report Series no. 462

3. FAO/WHO (1974) Toxicological evaluation of certain food additives with a review of general principles and of specifications. 17th Report of the Joint FAO/WHO Expert Committee on Food Additives. FAO Nutrition Meetings Report Series no. 53, WHO Technical Report Series no. 539

4. Joint FAO/WHO Expert Committee on Food Additives (1988) L-glutamic acid and its ammonium, calcium, monosodium and potassium salts. In: Toxicological Evaluation of Certain Food Additives and Contaminants. Cambridge University Press, New York, pp 97-161

5. Headache Classification Committee of the International Headache Society (IHS) (2013) The International Classification of Headache Disorders, 3rd edition (beta version). Cephalalgia 33(9):629-808

6. Tarasoff L, Kelly MF (1993) Monosodium L-glutamate: a double-blind study and review. Food Chem Toxicol 31(12):1019-35

7. Prawirohardjono W, Dwiprahasto I, Astuti I, Hadiwandowo S, Kristin E, Muhammad M, Kelly MF (2000) The administration to Indonesians of monosodium L-glutamate in Indonesian foods: an assessment of adverse reactions in a randomized double-blind, crossover, placebo-controlled study. J Nutr 130(4S Suppl):1074S-6S

8. Tanphaichitr V, Srianujata S, Pothisiri P, Sammasut R, Kulapongse S (1983) Post prandial responses to Thai foods with and without added monosodium L-glutamate. Nutr Rep Int 28:783-792

9. Zanda G, Franciosi P, Tognoni G, Rizzo M, Standen SM, Morselli PL, Garattini $S$ (1973) A double blind study on the effects of monosodium glutamate in man. Biomedicine 19:202-204

10. Morselli PL, Garattini S (1970) Monosodium glutamate and the Chinese restaurant syndrome. Nature (Lond) 227:611-612

11. Geha RS, Beiser A, Ren C, Patterson R, Greenberger PA, Grammer LC, Ditto AM, Harris KE, Shaughnessy MA, Yarnold PR, Corren J, Saxon A (2000) Multicenter, double-blind, placebo-controlled, multiple-challenge evaluation of reported reactions to monosodium glutamate. J Allergy Clin Immunol 106(5):973-80

12. Yang WH, Drouin MA, Herbert M, Mao Y, Karsh J (1997) The monosodium glutamate symptom complex: assessment in a double-blind, placebocontrolled, randomized study. J Allergy Clin Immunol 99(6 Pt 1):757-62

13. Shimada A, Cairns BE, Vad N, Ulriksen K, Pedersen AM, Svensson P, BaadHansen $L$ (2013) Headache and mechanical sensitization of human pericranial muscles after repeated intake of monosodium glutamate (MSG). $J$ Headache Pain 14(1):2

14. Baad-Hansen L, Cairns B, Ernberg M, Svensson P (2010) Effect of systemic monosodium glutamate (MSG) on headache and pericranial muscle sensitivity. Cephalalgia 30(1):68-76

15. Rosenblum I, Bradley JD, Coulston F (1971) Single and double blind studies with oral monosodium glutamate in man. Toxicol Appl Pharmacol 18(2): 367-73

16. Gore ME, Salmon PR (1980) Chinese restaurant syndrome: fact or fiction? Lancet 1(8162):251-2

17. Kenney RA, Tidball CS (1972) Human susceptibility to oral monosodium Lglutamate. Am J Clin Nutr 25:140-146

18. Merritt JE, Williams PB (2005) Vasospasm Contributes to Monosodium Glutamate-Induced Headache. Headache 30:575-580

19. Bizzi A, Veneroni E, Salmona M, Garattini S (1977) Kinetics of monosodium glutamate in relation to its neurotoxicity. Toxicol Lett 1:123-130

20. Lj S, Hagen K, Jensen R, Katsarava Z, Lipton R, Scher A, Steiner T, Zwart JA (2007) The global burden of headache: a documentation of headache prevalence and disability worldwide. Cephalalgia 27(3):193-210

21. Stegink LD, Baker GL, Filer LJ (1983) Modulating effect of sustagen on plasma glutamate concentration in humans ingesting monosodium Lglutamate. Am J Clin Nutr 37(2):194-200

22. Tsai PJ, Huang PC (2000) Circadian variations in plasma and erythrocyte glutamate concentrations in adult men consuming a diet with and without added monosodium glutamate. J Nutr 130(4S Suppl):1002S-4S

23. Beyreuther K, Biesalski HK, Fernstrom JD, Grimm P, Hammes WP, Heinemann U, Kempski O, Stehle P, Steinhart H, Walker R (2007) Consensus meeting: monosodium glutamate - an update. Eur J Clin Nutr 61(3):304-13 